\title{
Youth Journeys in Mental Health: Invoking Unique Patient Perspectives
}

\author{
Kate C. Tilleczek, Brandi L. Bell, Matthew A. Munro, and Sarah D. Gallant \\ University of Prince Edward Island
}

\begin{abstract}
We know much about the alarming trends in youth mental health; however, we know far less about the journeys that Canadian youth are taking toward better mental health. This article begins with a conceptual synthesis of the literature about the ways in which scholars are invoking the journeys of youth. We then present two examples of youth journeys in mental health from our current Atlantic Canada Children's Effective Service Strategies in Mental Health project (ACCESS-MH) and conclude that journey approaches to youth mental health research could support the implementation of Canada's mental health strategy in unique and crucial ways.
\end{abstract}

Keywords: youth mental health, research, patient journeys

\section{RÉSUMÉ}

Nous en savons beaucoup sur les tendances inquiétantes en santé mentale des jeunes ; cependant, nous en savons beaucoup moins sur le parcours que les jeunes Canadiens sont en train de suivre vers une meilleure santé mentale. Cet article commence par une synthèse conceptuelle de la littérature scientifique qui porte sur la manière dont les chercheurs traitent des parcours des jeunes. Nous présentons ensuite deux parcours de jeunes qui ont un problème de santé mentale et qui participent à notre projet Atlantic Canada Children's Effective Service Strategies in Mental Health (ACCESS-MH). Nous en concluons que la recherche en santé mentale des jeunes qui s'appuie sur les parcours des jeunes pourraient soutenir d'une manière unique et déterminante la mise en œuvre de la stratégie en santé mentale du Canada.

Mots clés : santé mentale des jeunes, recherché, parcours de patients.

Kate C. Tilleczek, Young Lives Research Laboratory (YLRL), University of Prince Edward Island, Charlottetown, PEI; Brandi L. Bell, Young Lives Research Laboratory (YLRL), University of Prince Edward Island, Charlottetown, PEI; Mathew A. Munro, Young Lives Research Laboratory (YLRL), University of Prince Edward Island, Charlottetown, PEI; Sarah D. Gallant, Young Lives Research Laboratory (YLRL), University of Prince Edward Island, Charlottetown, PEI.

This research was supported by the Canadian Institutes of Health Research (TT4-128269). Parts of this paper were previously published in Education Canada (Tilleczek \& Lezeu, 2014).

Correspondence concerning this article should be addressed to Dr. Kate Tilleczek, Young Lives Research, University of Prince Edward Island, 550 University Ave., Charlottetown, PE C1A 4P3. Email: ktilleczek@upei.ca 


\section{CONTEXT}

Young people with mental health challenges are both vulnerable and courageous. We have shown elsewhere that their lives can be difficult and stigmatized as they navigate a sea of additional troubles such as poverty, loneliness, marginalization, fear, and frustration that lead to multiple daily hassles (Seidman, Allen, Aber, Mitchell, \& Feinman, 1994; Tilleczek \& Lezeu, 2014), spirals of decline (Tilleczek \& Campbell, 2013), and/or cultures of silence (Kutcher \& McLuckie, 2010).

We know much about the new and alarming trends in mental health challenges in the lives of Canadian youth. Out of the Shadows at Last (Kirby \& Keon, 2006) first demonstrated the urgency of this issue and the Canadian Mental Health Association now estimates that 10-20\% of Canadian youth are affected by a mental illness, with 3.2 million youth 12-19 years of age at risk for developing depression (Canadian Mental Health Association, n.d.). Others estimate that $30 \%$ of students indicate psychological distress (Paglia-Boak et al., 2010) with only one in five receiving formal supports, suggesting some of the explanation for why Canada's youth suicide rate is the third highest in the industrial world (Costello, Egger, \& Angold, 2005). We also know that growth in social inequality and poverty are closely related to mental health for youth (Tilleczek, 2016; Tilleczek, Ferguson, Campbell, \& Lezeu, 2014). Youth from impoverished backgrounds are three times more likely than their wealthier peers to experience mental health challenges (Lipman \& Boyle, 2008). The most pressing factors in poor mental health include poverty, learning difficulties, abuse/neglect, isolation, lack of support, and lack of access to quality health care and education (Lipman \& Boyle, 2008).

However, we know far less about the journeys that young people are taking toward better mental health through the current system of mental health care. Youth journeys are important for understanding youth mental health trends and system responses as they invoke unique narrative and visual perspectives from within and across systems of illness and healing. Indeed, Changing Directions, Changing Lives: The Mental Health Strategy for Canada (the Strategy; Mental Health Commission of Canada [MHCC], 2012) places emphasis on recovery as "a process or journey of healing" such that individuals can live "a satisfying, hopeful, and contributing life, even when there are on-going limitations caused by mental health problems and illnesses" (p. 34). A foundational principle of the Strategy is that "people who experience mental health problems and illnesses are treated with dignity and respect" (MHCC, 2012, p. 16). Therefore, understanding how journeys through mental health are experienced by youth provides important responses to the Strategy such that we can better see and attend to the journey of healing and provide these youth with opportunities to meaningfully contribute to improving the mental health system in Canada.

The inclusion of youth journeys is a timely aspect of policy and research. It is now well recognized that people with firsthand knowledge and experience have the most insight into the ways in which supports, services, and treatments can be aligned to foster recovery (Addiction and Mental Health Collaborative Project Steering Committee, 2014; MHCC, 2012). Numerous examples of youth engagement exist in mental health policy and program development across Canada, including the MHCC's Youth Council, the Centre of Excellence for Youth Engagement/The Students Commission, provincial youth advisory groups and engagement strategies, Jack.org, mindyourmind, and others. Similarly, academic research with youth has

experienced a shift towards child/youth-centred participatory research. Researchers are increasingly using participatory and visual research methods with children and youth to provide meaningful ways to elicit rich 
experiential data with, for, and by youth (Cappello, 2005; Carter \& Ford, 2013; Clark, 1999; Mitchell, 2006; Tilleczek \& Kinlock, 2013; Tilleczek \& Loebach, 2015). We contend that research approaches focused on the journeys of youth with mental health challenges and employing visual methods can engage those with lived experiences to improve knowledge, build collaborative relationships, and meaningfully involve children and youth in identifying and addressing mental health system challenges.

This paper begins by providing a conceptual synthesis of the literature about the ways in which scholars invoke journeys of youth. We then present these methods as we have applied them with Canadian youth in our five year Canadian Institutes of Health Research (CIHR) funded project, Atlantic Canada Children's Effective Service Strategies in Mental Health (ACCESS-MH). We demonstrate, with two exemplars, that journeys could be well used in youth mental health research to support the implementation of the Strategy in ways that reflect its spirit of "hope, empowerment, self-determination, and responsibility" (MHCC, 2012, p. 16) while addressing the priority to "improve mental health data collection, research, and knowledge exchange across Canada" (p. 114).

\section{INVOKING JOURNEYS}

Journey mapping is an approach to research that gathers stories from health system clients and provides visual and narrative maps of the barriers and facilitators encountered in navigating access and care (Bell \& Deyell, 2016; Tilleczek \& Bell, 2015; Tilleczek, Bell, \& Deyell, 2015; Tilleczek \& Lezeu, 2014). This approach is beginning to be used by international researchers and our recent scoping review of this literature on journeys in youth mental health found it slight in number, but revealing. Our scoping review of recent published academic materials consulted Google Scholar, Academic Search Complete, CINAHL, Education Research Complete, PsychINFO, and MEDLINE. Using combinations and variations of the terms patient, journeys, mental health, pathways, primary health care, encounter form, patient mapping, qualitative, young people, adolescence, and youth, the search yielded 25 English-language journal articles from Canada, Italy, Eastern Europe, New Zealand, United States, United Kingdom, India, and China. Research studies and summaries of literature published in academic journals in 2000 or later and pertaining to patient journeys and youth mental health were included.

Three themes arose from our analysis of this literature: Youth journeys in mental health are often fractured and non-linear; barriers and facilitators exist at personal and systemic levels and often in paradoxical fashion, and schools are crucial locations in youth journeys. Young people take individualized and dynamic journeys to seeking mental health supports (Boydell et al., 2006) and these journeys often start long before they receive formal care from a primary health care provider, often beginning with early experiences and interactions at home and in school (de la Rie, Noordenbos, Donker, \& van Furth, 2006; Scott, 2012). The non-linear character of these journeys shows us where we could best intervene in an often fractured system. Figure 1 illustrates these analytical themes through the use of a journey exemplar. The paradoxical journey model demonstrates how personal and systemic structures and people can exacerbate problems that accompany mental health challenges. For example, while there is a shortage of skilled mental health professionals in some areas, most work very hard on a daily basis to go above and beyond their job descriptions in providing excellent care. Also, while poverty stretches the resources of families, many parents are going to extraordinary lengths to advocate for their children in the face of great adversity. Thus, mirror image supports exist 
for each barrier as evidenced in a surprising range of facilitators from which we must launch meaningful change. Teachers, parents, friends, and mental health professionals could form a core community of helpers. School peers are identified as silent actors in the journey with a role that remains both unclear and complex. Schools must do better in providing safe and fulsome spaces for learning about all aspects of mental health (Boydell, Volpe, Gladstone, Stasiulis, \& Addington, 2013).

In summary, the invocation of patient journeys provides a unique participatory, narrative, and visual approach to youth mental health research. While scant at present, the research provides promising direction for the collection and dissemination of research data that respects the lived experiences and vast knowledge of youth with mental health challenges and values their contributions to understanding systemic barriers and facilitators to recovery.

\section{ACCESS-MH PATIENT JOURNEYS}

Our team of researchers across Atlantic Canada is deepening understanding of child/youth mental health in the region. The ACCESS-MH project is a 5-year initiative funded by the CIHR. It employs the newest knowledge on youth journeys and arts-based methods and melds it with the analysis of provincial and national statistical data (e.g., provincial administrative data and statistics, Statistics Canada, Health Canada, CIHI, NLSCY). Led by a team of five researchers who bring diverse experiences and expertise in health economics, operations research, clinical psychology, research with, for and by youth, and qualitative research methods, it is also informed by an advisory committee with representation from multiple sectors and across the four Atlantic provinces. The combination of quantitative and qualitative methods provides an opportunity to examine mental health conditions and the mental health system from a variety of perspectives. Our journeys approach is especially suited to understanding the complex contexts of young lives.

\section{Theoretical approach}

The sociological imagination is at the core of the Complex Cultural Nesting theory (Tilleczek, 2011, 2014) which links history (becoming) to time (being) to society (belonging; see Figure 2). It shines an illustrative light on how young people and those closest to them are inseparable from historical and current social systems and extends Bronfenbrenner's (1979) description of the levels at which social influences occur. The concentric systems - chronosystem, exosystem, macrosystem, mesosystem, and microsystem-are well known by health researchers who describe contexts of development in which "every transition is both a consequence and an instigator of developmental processes" (p. 27). However, Complex Cultural Nesting makes a further move in drawing on Elder's (1997) life course model, the socioeconomic gradient, and income inequality models (Keating \& Hertzman, 1999; Wilkinson \& Pickett, 2009), as well as the sociological insights of Smith $(1987,2002)$ and Mills (1959).

As defined by Bronfenbrenner (1979), social ecological contexts include the microsystem as a pattern of activities, roles, and interpersonal relations that people experience in a given setting. To this is added the centrality of narrative and biography that play a crucial role in portraying "accounts which contain transformation (change over time), some kind of 'action' and characters, all of which are brought together within 
Figure 1

Journey map of scoping review analytical themes
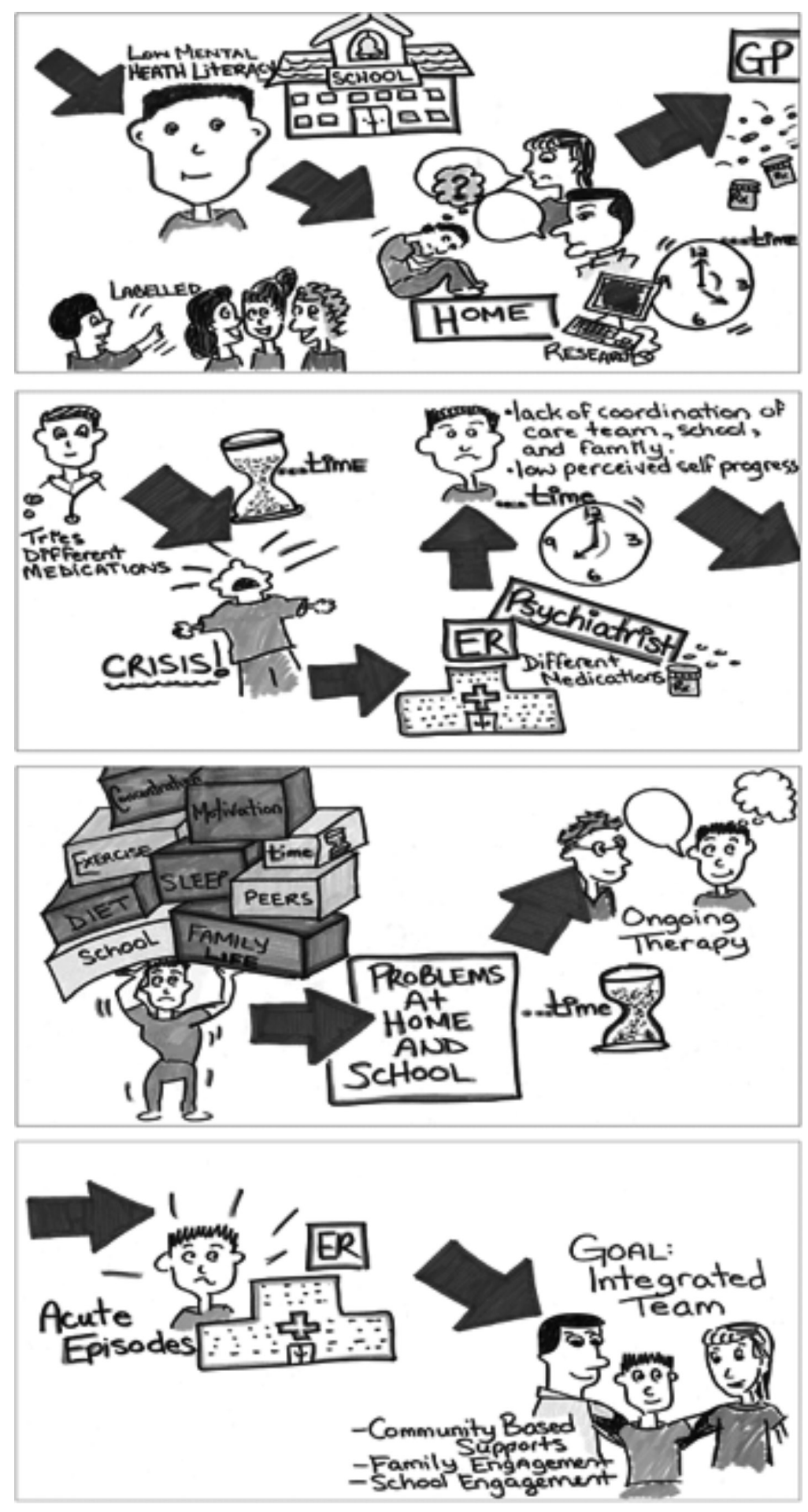

Source: Tilleczek \& Lezeu, 2014) 
an overall 'plot' - are a central means with which people connect together past and present, self and other" (Lawler, 2002, p. 242).

The mesosystem is "a system of microsystems" (Bronfenbrenner, 1979, p. 25) in which relations have indirect or direct bearing on young people's lives. They hold the interrelations among people in two or more settings in which we actively participate - a theoretically important point in youth studies since it allows for analyses of negotiation, resistance and re-enactment. This in-between system holds experience and embodiment of intersections such as those of social class, poverty, ethnicity, identity, and age that are played out.

Figure 2

\section{Complex Cultural Nesting theoretical approach}

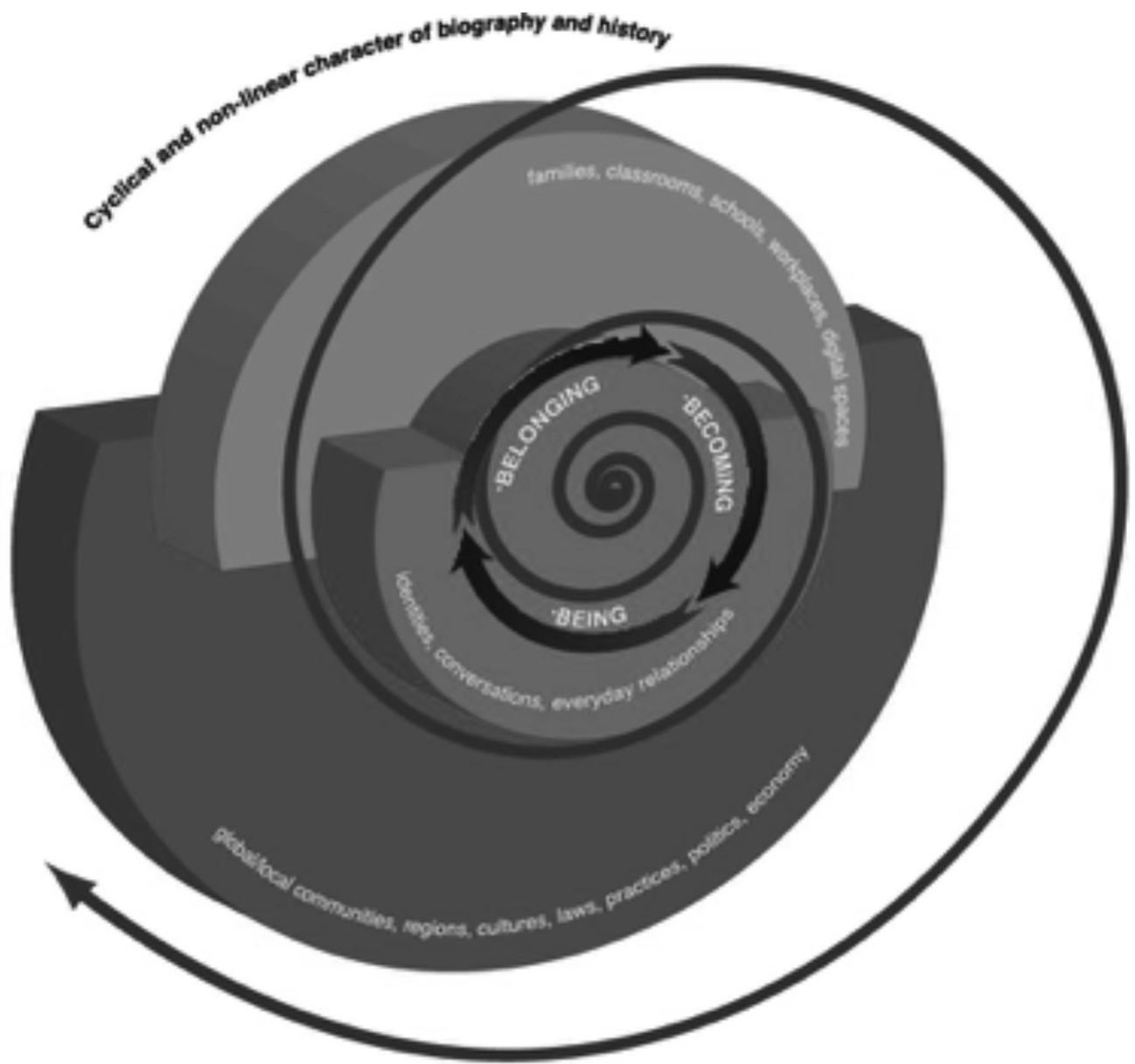

"Pepresents the tindamental social process of youth devetcopentent (actoss social, emotional. physical, psychotogical, efc.); each occurs in all nested corbents and across transitional points.

Source:Tilleczek 2011;2014; 2016 
The macrosystem refers to patterns, consistencies, and inconsistencies at the level of society, including the enacting of politics, governance, laws, and ideologies. To this is added the profound and expansive anthropological and sociological literature concerning the constitution and negotiation of society and culture. The chronosystem - the timing and patterning of lives - provides focus to the analyses of history and time and involves the "scientific study of progressive, mutual accommodations between an active, growing human being and the changing properties of the immediate settings" (Bronfenbrenner, 1979, p. 21).

Sociological theory has much to contribute by way of understanding social relationships and social relations. The notions of bi-directionality and inter-relationships among people and systems are of particular relevance. Development and time are not easily determined linear pathways and time and growth are conceived as non-linear and dynamic (Furlong, Cartmel, Biggart, Sweeting, \& West, 2003; Tilleczek, 2012, 2014) and nested within complex modern and super-modern cultures (Auge, 1995). When we understand young lives in this nuanced way, our methods are participatory with, for, and by youth and analysis is grounded in their biography (being), time (becoming), and society (belonging; Tilleczek, 2014).

\section{Methodology}

In keeping with the ecological Complex Cultural Nesting theory, the ACCESS-MH patient journeys study has been designed to examine bi-directional, nested, and dynamic human and institutional relationships. The patient journeys invoke a critical ethnography using humanities-infused praxis with, for, and by youth (Tilleczek, 2014; Tilleczek \& Kinlock, 2013). This form of critical ethnography includes elements of institutional ethnography (Smith, D. 2006; Smith, D. E., 1987, 2002,) as "inquiry intended to disclose how activities are organized and how they are articulated to the social relations of the larger social and economic process" (Smith, 1987, p. 151). These methods provide a way of examining social processes and systems in which social inequalities are problematic and/or resisted (Foley \& Valenzuela, 2005; Madison, 2005). Researchers co-locate in the daily lives of youth and families to discern meaning in conjunction with participants (Campbell \& Gregor, 2002; DeVault \& McCoy, 2002).

\section{Methods}

Research ethics. Undertaking research requires careful attention to the ethical principles of respect for persons, concern for welfare, and justice (Canadian Institutes of Health Research, Natural Sciences and Engineering Research Council of Canada, \& Social Sciences and Humanities Research Council of Canada, 2014). The ACCESS-MH patient journeys study received approval from the Research Ethics Boards at the five principal Atlantic Canada research institutions (UPEI, UNB, MUN, MSU, UdeM) and other institutional bodies including health authorities and school boards.

Participants and recruitment. This longitudinal study involves patient journey interviews with 164 participants at Time I (2014-16) and follow-up interviews with one quarter of those participants at Time II (2016-17). We adhere to rules of thumb of qualitative maximum variation sampling of participants (Tilleczek, 2008, 2012) who have experienced the phenomenon under study to reach thick saturation of qualitative data (Morse, 2000). Interviews are being conducted with three groups: Children/youth, parents/guardians, and service providers. Each participating child/youth (aged 10-18) either has a current diagnosis for at least 
one common child/youth mental health condition (i.e., autism spectrum disorders, conduct disorder, eating disorders, anxiety, depression) or is currently self-identified as dealing with at least one of these conditions (e.g., waiting for diagnosis). Similarly, each parent/guardian participant has legal authority to care for a child/ youth (aged 5-18) with the same diagnositic criteria. Service providers are selected to ensure representation across the mental health system. This includes medical service providers who provide healthcare services (or are in an administrative role) as well as community-based service providers who work in a community organization or school and who provide services to individuals, families, or communities (or are in an administrative role).

Patient journeys interviews. We use qualitative in-depth interviews to obtain the perspectives of these participants (Fontana \& Frey, 2005; Minichiello, Aroni, Timewell, \& Alexander, 1995; Smyth \& Hattam, 2001). This technique is a narrative conversation with a specific purpose to focus "on the informant's perception of self, life, and experience, and expressed in his or her own words" (Minichiello et al., 1995, p. 61).

Each interview begins with the researcher explaining the project, carefully reviewing the consent information with the participant, and gaining informed consent. The participant then completes a short demographic questionnaire. As the interview itself begins, the researcher asks semi-structured questions and engages the participant in conversation. A blank felt board is set up during the interview and participants are prompted to create a visual map of the journey they are describing using items representing people, places, items, feelings, etc. (see Figures 3 and 4).

\section{ALEXANDER AND EVE: TWO YOUTH JOURNEY EXEMPLARS}

The following two journey narratives illustrate this process. The first journey is one in which there are complex resiliencies in that supports coexist with barriers and depend upon location. The second tells the story of a more troubled journey with multiple risks in a labyrinth rather than a cohesive system.

\section{Alexander: Complex Resiliencies and Supports (Figure 3)}

Alexander (a pseudonym) is a 14 year-old youth who lives in a rural Atlantic Canada town and was formally diagnosed with an anxiety disorder at the age of four. He was quite willing to participate in our project, wanting to share his story. However, at the time of the interview he became apprehensive about being audio recorded. Instead, he felt more comfortable talking without a recording device in the room. As a result, the patient journey mapping board became a critical piece in his storytelling process.

Alexander recalled that when he was four years old his mother took him to see the family doctor regarding his anxiety. The family doctor conducted blood work and the participant was prescribed, and began taking, medication for an anxiety disorder. This is represented on the journey map with doctor and medication icons. His experience with this initial treatment was not a positive one and his anxiety problems worsened over time.

Approximately five years later, at the age of nine, his anxiety levels became critical and he attended therapy sessions with a private counsellor as depicted on the journey map with a clock and therapist icons. He described "hating" this experience and stopped after a few sessions. This was another negative experience 
Figure 3

\section{Alexander's journey map}

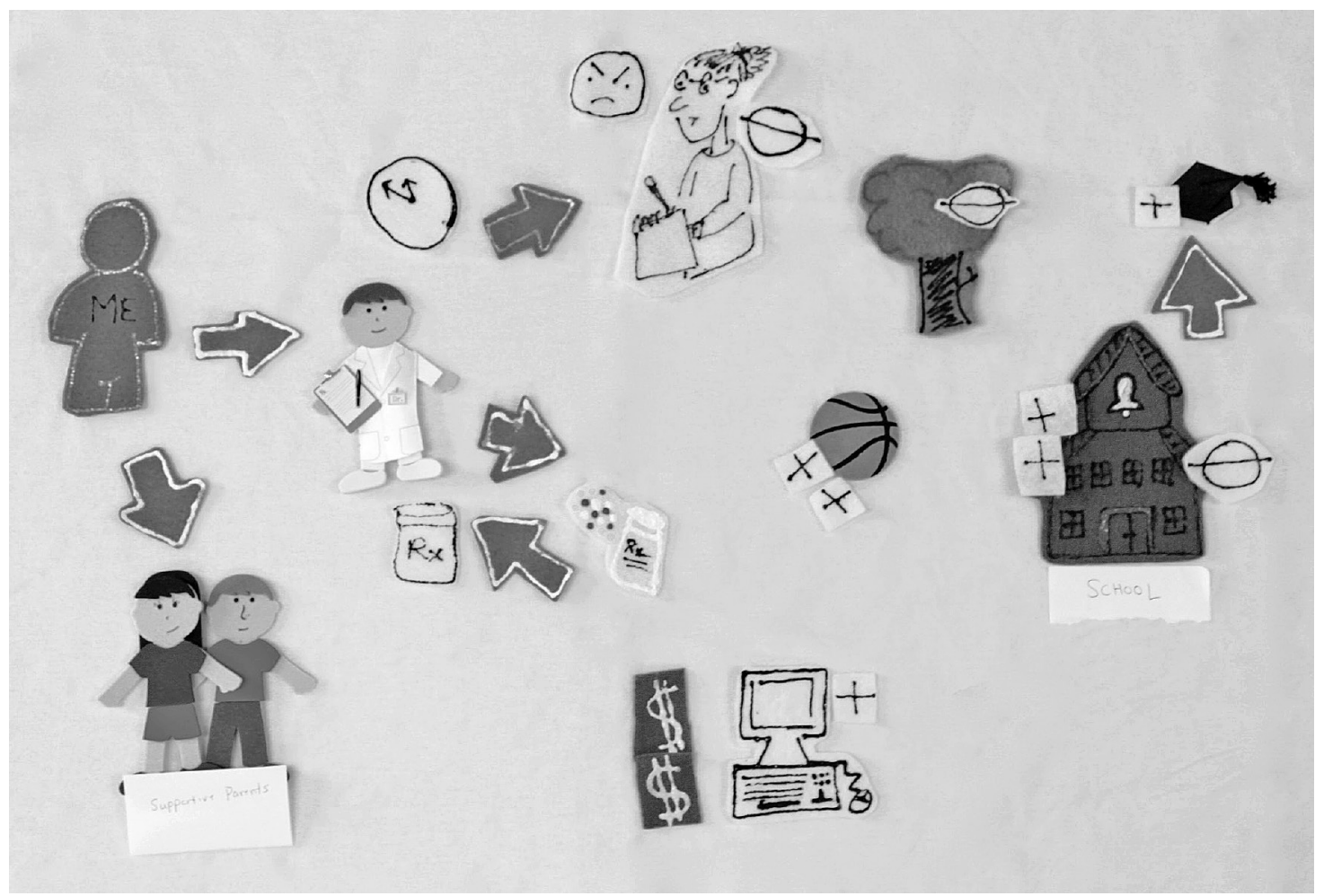

which he indicated on the map with a minus symbol. After the failed attempt at therapeutic support, Alexander returned to the family doctor who proceeded with additional blood work. The result was a stronger prescription from his family doctor as indicated on the journey mapping board. The participant described this as a more positive experience and said that from that point on his anxiety became more stabilized.

Moving from the healthcare system to the education system was an important part of Alexander's journey. He described not feeling anxiety symptoms at home, but they would manifest primarily at school by feeling sick to his stomach. Missed class time was an ongoing problem throughout his entire education. One of his major goals is to break the negative association he has with school and to make it a positive place. Alexander has received support from his teachers, counsellors, and the administration. They have taken a vested interest in his health and well-being and, although it is still a daily struggle to attend school comfortably, his attendance and grades are improving. This paradoxical relationship with school is represented with positives and negatives icons on the map.

Another school-based facilitator for positive mental health has been the support and motivation he receives from playing basketball. When Alexander saw the basketball image in the mapping kit he elaborated at length that playing on the basketball team has been very important for his physical and social activity. 
Because he cannot play games with the team when he is absent from school this has created a new motivation to attend class regularly.

Friends and family did not play a primary role in Alexander's journey. Instead, the image of a computer in the mapping kit prompted much discussion. A main goal in his recent year has been to earn money for the upkeep of his computer including software upgrades. This has motivated him to work at a part-time job throughout the school year. He explained that outside of school and basketball much of his time is spent online. He did not view this as alone time but rather social time with his online gaming community. He contrasted this with outdoor time saying he does not enjoy being outside. This is depicted on the journey map with positives icons around the computer, and dollar signs indicating the money he earned, whereas the tree-shaped object carries a negative connotation for Alexander. In these instances the journey mapping process prompted discussion regarding elements of social life that otherwise may not have been prompted from semi-structured interview alone.

\section{Eve: Multiple Risks in a Labyrinth (Figure 4)}

This journey narrative is from a 16-year-old youth named Eve (a pseudonym) who has been diagnosed with anxiety and obsessive compulsive disorder (OCD) while also self-identifying as having depression. Her journey map outlines the people, relationships, and structures involved in facilitating access to care for her mental health challenges, as well as the barriers she faced. Eve begins the journey in her early childhood as she enters the school system at age 5 . She remembered becoming frustrated and overwhelmed in the school setting, often struggling with tasks in comparison to other children. This is shown on the upper left-hand side of the journey map with the school building and the "me" character with a sad face. Crying was her outlet for dealing with this frustration, for which she was consistently teased by her classmates.

As Eve grew older and entered primary school and junior high, her frustrations in the classroom continued and turned to difficulties coping with gym class and athletics. Eve started seeing the school guidance counsellor in primary school, but drifted out of school guidance care as she transitioned through junior high. At age 16 she now meets with her high school guidance counsellor but faces long wait-times due to the high number of youth at her school with mental health needs.

Eve discusses her family situation as difficult, especially her relationship with her father. She feels that this is connected to her mental health diagnoses and sexual orientation. Her openness about being a lesbian is illustrated on the journey map with the me piece connected by a heart to another young woman. Her parents are standing beside them on the map but the circle has a strike through it signifying that she is misunderstood. She is also distrustful because her parents, friends, and some service providers have previously broken her confidentiality regarding private mental health information. Following Eve's attempt to open up to a friend about her self-harming behaviours and suicidal thoughts, represented on the map as a sad face on the me character beside a knife and a blade, several classmates began spreading rumors about her online. They claimed that she was "attention-seeking." Eve depicted this event by placing a computer overlapped with an angry face next to a circle with a strike through it with four peers standing beside the computer.

After sharing details of her self-harm and suicidal ideation with her mother when she felt she had no other source of support, Eve's mother decided to seek help for her daughter from a psychologist. Eve 
Figure 4

\section{Eve's journey map}

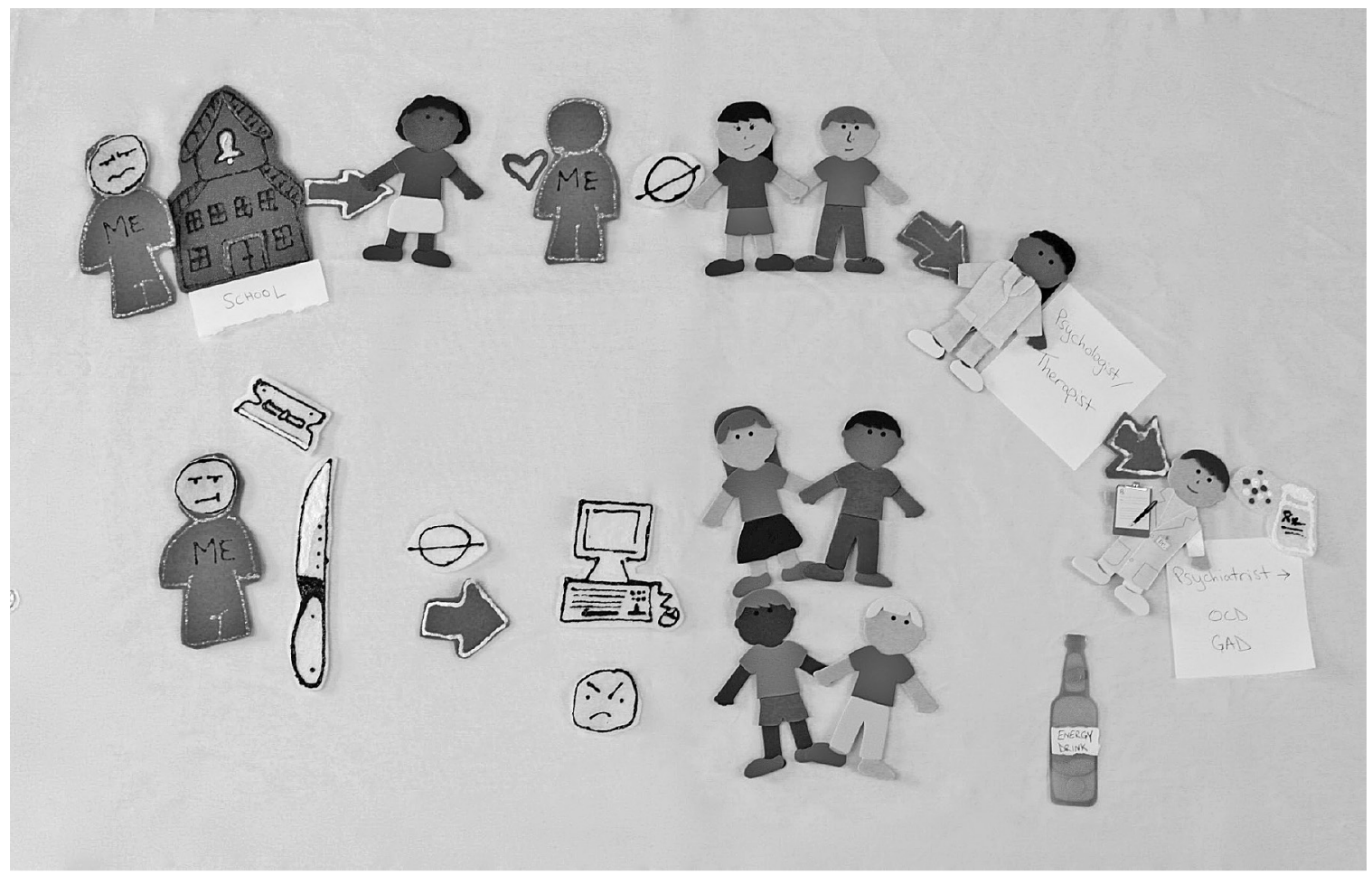

reluctantly went to see the psychologist with her mother, eventually finding it to be somewhat helpful but identifying travel time and cost as two major barriers in her care. Her mother was forced to take time away from work and Eve missed classes. As Eve began therapy with the psychologist, she developed extremely restrictive eating patterns and excessive exercising leading her to self-identify as having an eating disorder and depression. Eve was referred to a psychiatrist and an eating disorder outpatient treatment centre.

After a month on a wait list, Eve had an appointment with the psychiatrist who did not believe she had either depression or an eating disorder. Rather, these were diagnosed as symptoms of generalized anxiety disorder and OCD. The psychiatrist removed Eve from the wait list for the eating disorder treatment centre and instead prescribed Prozac to address anxiety and OCD. Eve indicated that she did not feel that her self-diagnoses of depression or eating disorder were taken seriously. She had difficulty adjusting to the medication, which she claimed was not normally given to individuals under the age of 18 unless they had OCD. She reported that the medication began to improve some of her symptoms but made others worse. In addition to the medication, she finds herself using other substances such as energy drinks (shown on the far right side of the journey map) to temporarily improve her mood. She still feels strongly that she cannot cope with the mental health challenges that she faces, noticing this especially when she runs out of medication or when she is not able to connect with anyone for support. She speaks about her desire to be able to deal with common challenges that she faces and is unsure how she will be able to accomplish anything in life. 
The most cumbersome barrier for Eve is that she is unable to get the proper support that she needs at the time she needs it. She sees her psychiatrist regularly, but does not feel that there is adequate assistance when she feels depressed, suicidal, and does not want to go to the emergency room. She continues to experience challenges at school with classmates and some teachers who do not take mental illness seriously. She struggles to find support from the people around her and identifies with those who are oppressed due to their sexual orientation, gender identity, and mental health conditions, understanding firsthand the personal and systemic obstacles that are experienced as a result of these differences.

\section{SUMMARY AND DIRECTIONS}

Our scoping review and research project uphold important messages about youth mental health in response to the Mental Health Strategy for Canada (MHCC, 2012). We contend that the Strategy shows Canada is moving along a good path in addressing alarming trends in youth mental health. We offer youth journeys as a unique way to examine the lives of young Canadians and point to promising new ways to support them. Learning from those with lived experience will better address mental health system issues such as service coordination, reduction in wait times, stigma, and spaces for families, schools, and mental health professionals to assist in journeys of recovery. Through such means we "make significant progress in our ability to understand what is working well to improve mental health and well-being and to use this expanded knowledge to measure progress in transforming the system and improving outcomes" (MHCC, 2012, p. 114). Our findings suggest that family, peer, and community members play key roles in youth journeys and create communities of support for youth as they access and navigate care and recovery. However, even with these supports in place many youth continue to struggle. In cases where these supports are not available, journeys become more fractured still and many youth fall through the cracks, hoping they are still on someone's wait-list and will someday be supported. Navigation of this system is complex and those who do it well have acquired a detailed literacy of both the overt and covert pathways to care. Bearing witness to youth journeys calls us back to action in breaking the spirals of decline and cultures of silence that too often exist in the youth mental health system. And, it does so with the possibility of inviting these young people into a dignified conversation that could help to lead the call and response of research, policy, and action.

\section{REFERENCES}

Addiction and Mental Health Collaborative Project Steering Committee. (2014). Collaboration for addiction and mental health care: Best advice. Ottawa, ON: Canadian Centre on Substance Abuse.

Auge, M. (1995). Non-places: An introduction to an anthropology of supermodernity. London: Verso Press.

Bell, B. L., \& Deyell, T. (2016). Patient journeys in youth mental health: Arts-based methods for exploring youth, parent, and service provider perspectives. Paper presented at the 3rd ISA Forum of Sociology. Vienna, Austria, July 10-14.

Boydell, K., Pong, R., Volpe, T., Tilleczek, K., Wilson, E., \& Lemieux, S. (2006). Family perspectives on pathways to mental health care for children and youth in rural communities. Journal of Rural Health, 22(2), 182-188.

Boydell, K. M., Volpe, T., Gladstone, B. M., Stasiulis, E., \& Addington, J. (2013). Youth at ultra high risk for psychosis: Using the Revised Network Episode Model to examine pathways to mental health care. Early Intervention in Psychiatry, 7(2), 170-186. doi:10.1111/j.1751-7893.2012.00350.x

Bronfenbrenner, U. (1979). The ecology of human development. Cambridge: Harvard University Press.

Campbell, M. L., \& Gregor, F. M. (2002). Mapping the social. Aurora, ON: Garamond Press. 
Canadian Institutes of Health Research, Natural Sciences and Engineering Research Council of Canada, and Social Sciences and Humanities Research Council of Canada. (December 2014). Tri-Council Policy Statement: Ethical Conduct for Research Involving Humans. Ottawa: Interagency Secretariat on Research Ethics.

Canadian Mental Health Association. (n.d.). Fast facts about mental illness. Retrieved from http://www.cmha.ca/media/ fast-facts-about-mental-illness/\#.Us1uj7SmYk8

Cappello, M. (2005). Photo interviews: Eliciting data through conversations with children. Field Methods, 17(2), 170-182. doi: $10.1177 / 1525822 \times 05274553$

Carter, B., \& Ford, K. (2013). Researching children's health experiences: The place for participatory, child-centered, arts-based approaches. Research in Nursing \& Health, 36(1), 95-107. doi:10.1002/nur.21517

Clark, C. D. (1999). The autodriven interview: A photographic viewfinder into children's experience. Visual Studies, 14(1), 39-50. doi:10.1080/14725869908583801

Costello, E. J., Egger, H., \& Angold, A. (2005). 10-year research update review: The epidemiology of child and adolescent psychiatric disorders: I. Methods and public health burden. Journal of the American Academy of Child and Adolescent Psychiatry, 44(10), 972-986. doi:10.1097/01.chi.0000172552.41596.6f

de la Rie, S., Noordenbos, G., Donker, M., \& van Furth, E. (2006). Evaluating the treatment of eating disorders from the patient's perspectives. International Journal of Eating Disorders, 39(8), 667-676. doi:10.1002/eat.20317

DeVault, M. L., \& McCoy, L. (2002). Institutional ethnography. In J. Gubrium \& J. Holstein (Eds.), Handbook of interview research (pp. 751-775). Thousand Oaks, CA: SAGE.

Elder, G. H., Jr. (1997). The life course and human development. In W. Damon \& R. M. Lerner (Eds.), Handbook of child psychology (pp. 939-991). NY: Wiley.

Foley, D., \& Valenzuela, A. (2005). Critical ethnography. In N. K. Denzin \& Y. S. Lincoln (Eds.), The SAGE Handbook of qualitative research (3rd ed.; pp. 217-234). Thousand Oaks, CA: SAGE.

Fontana, A., \& Frey, J. H. (2005). The interview: From neutral stance to political involvement. In N. K. Denzin \& Y. S. Lincoln (Eds.), The SAGE Handbook of qualitative research (3rd ed.; pp. 695-728). Thousand Oaks, CA: SAGE.

Furlong, A., Cartmel, F., Biggart, A., Sweeting, H., \& West, P. (2003). Youth transitions: Patterns of vulnerability and processes of social inclusion. Edinburgh: Scottish Executive Social Research.

Keating D. P., \& Hertzman, C. (1999). Developmental health and the wealth of nations. New York: The Guildford Press.

Kirby, M. J. L., \& Keon, W. J. (2006). Out of the shadows at last: Transforming mental health, mental illness and addiction services in Canada. Ottawa, ON: Standing Senate Committee on Social Affairs, Science and Technology. Retrieved from http://www.parl.gc.ca/content/sen/committee/391/soci/rep/rep02may06-e.htm

Kutcher, S., \& McLuckie, A. for the Child and Youth Advisory Committee, Mental Health Commission of Canada. (2010). Evergreen: A child and youth mental health framework for Canada. Retrieved from http://www.mentalhealthcommission.ca/English/system/files/private/document/C\%2526Y_Evergreen_Framework_ENG_0.pdf

Lawler, S. (2002). Narrative in social research. In T. May (Ed.), Qualitative research in action (pp. 242-258). London: SAGE.

Lipman, E. L., \& Boyle, M. (2008). Linking poverty and mental health: A lifespan view. Retrieved from http://www. excellenceforchildandyouth.ca/sites/default/files/position_poverty.pdf

Madison, D. S. (2005). Critical ethnography as street performance: Reflections of home, race, murder, and justice. In N. K. Denzin \& Y. S. Lincoln (Eds.), The SAGE Handbook of qualitative research (3rd ed.; pp. 537-546). Thousand Oaks, CA: SAGE.

Mental Health Commission of Canada. (2012). Changing directions, changing lives: The mental health strategy for Canada. Calgary, AB: Author. Retrieved from http://strategy.mentalhealthcommission.ca/pdf/strategy-imagesen.pdf

Mills, C. W. (1959). The sociological imagination. London: Oxford University Press.

Minichiello, V., Aroni, R., Timewell, E., \& Alexander, L. (1995). In-depth interviewing: Principles, techniques, analysis (2nd ed.). Melbourne: Longman Cheshire.

Mitchell, L. M. (2006). Child-centered? Thinking critically about children's drawings as a visual research method. Visual Anthropology Review, 22(1), 60-73.

Morse, J. M. (2000). Determining sample size. Qualitative Health Research, 10(1), 3-5.

Paglia-Boak, A., Mann, R. E., Adlaf, E. M., Beitchman, J. H., Wolfe, D., \& Rehm, J. (2010). The mental health and well-being of Ontario students 1991-2009: Detailed OSDUHS findings (CAMH Research Document Series No. 
29). Retrieved from http://www.camh.ca/en/research/news_and_publications/ontario-student-drug-use-and-healthsurvey/Documents/2009\%20OSDUHS\%20Docs/Detailed_MHReport_2009OSDUHS_Final_Corrected.pdf

Scott, S. (2012). Kamloops Patient Journey Mapping Report, Child and Youth Mental Health. Retrieved from https:// divisionsbc.ca/Media/WebsiteContent/5500/Final\%20Kamloops\%20Patient\%20Journey\%20Mapping\%20 Report\%20CYMH\%2026-1.11.2012.pdf

Seidman, E., Allen, L., Aber, J. L., Mitchell, C., \& Feinman, J. (1994). The impact of school transitions in early adolescence on the self-system and perceived social context of poor urban youth. Child Development, 65, 507-522.

Smith, D. (2006). Institutional ethnography as practice. Toronto: Bowman and Littlefield Publishers, Inc.

Smith, D. E. (1987). The everyday world as problematic: A feminist sociology. Toronto: U of T Press.

Smith, D. E. (2002). Institutional ethnography. In T. May (Ed.), Qualitative research in action (pp. 17-52). London: SAGE.

Smyth, J., \& Hattam, R. (2001). "Voiced" research as a sociology for understanding "dropping out" of school. British Journal of Sociology of Education, 22(3), 401-415. doi:10.1080/01425690120068006

Tilleczek, K. (Ed.). (2008). Why do students drop out of high school? Narrative studies and social critiques. New York, NY: Edwin Mellen Press.

Tilleczek, K. (2011). Approaching youth studies: Being, becoming, and belonging. Toronto: Oxford University Press.

Tilleczek, K. (2012). Policy activism with and for youth transitions through public education. Journal of Educational Administration and History, 44(3), 253-267.

Tilleczek, K. (2014). Theorizing youth: Biography, society and time. In A. Ibrahim \& S. R. Steinberg (Eds.), Critical youth studies reader (pp. 15-25). New York: Peter Lang Press.

Tilleczek, K. (2016). Mental health in the middle years: Intersections and directions. Policy research synthesis paper for Ontario Ministry of Child and Youth Services. Toronto, Canada.

Tilleczek, K., \& Bell, B. L. (2015). Voices and journeys in child/youth mental health: Hearing from children/youth, parents, and service providers. Paper presented at the Atlantic Summer Institute on Healthy and Safe Communities: Investing in Child and Youth Mental Health - Mobilizing Atlantic Canadians for a Positive Future. Charlottetown, PE, August 19.

Tilleczek, K., Bell, B. L., \& Deyell, T. (2015). Youth voices and journeys in mental health: Arts-based methods for invoking unique patient perspectives. Paper presented at the Qualitative Health Research Conference 2015. Toronto, ON, October 19-21.

Tilleczek, K., \& Campbell, V. (2013). Barriers to youth literacy: Sociological and Canadian insights. Language and Literacy, 15(2), 77-100.

Tilleczek, K., Ferguson, M., Campbell, V., \& Lezeu, K. E. (2014). Mental health and poverty in young lives: Intersections and directions. Canadian Journal of Community Mental Health, 33(1), 63-76. doi:10.7870/cjemh-2014-006

Tilleczek, K., \& Kinlock, K. (2013). Humanities infused praxis by, with and for youth: Esoteric hope. In K. Tilleczek, K. \& B. Ferguson (Eds.), Youth, education and marginality: Local and global expressions (pp. 17-39). Waterloo, Canada: Wilfred Laurier University Press.

Tilleczek K., Laflamme, S., Ferguson, B., Roth Edney, D., Cudney, D., Girard, M., \& Cardoso, S. (2010). Fresh starts and false starts: Young people in transitions from elementary to secondary school. Hospital for Sick Children (Report to the Ontario Ministry of Education). Toronto, Canada: Queen's Printer. Retrieved from http://www. edu.gov.on.ca/eng/teachers/studentsuccess/Finalstudy.pdf

Tilleczek, K., \& Lezeu, K. (2014). Journeys in youth mental health: Complex young lives in a fractured system. Education Canada, 54(2), 12-16.

Tilleczek, K., \& Loebach, J. (2015). Research goes to the cinema: The veracity of videography with, for and by youth. Journal of Research in Comparative and International Education. Special Issue on the potential of videography in comparative education.

Wilkinson, R., \& Pickett, K. (2009). The spirit level. New York: Penguin. 